ASSOCIATIVE MEANING IN HOHO LYRICS OF

NIAS TRADITIONAL SONG

AN ARTICLE

Submitted in Partial Fulfillment of the Requirements

For the Degree of Sarjana Sastra

By:

DEVY KRISTIANA WAU

Registration Number : 2121220003

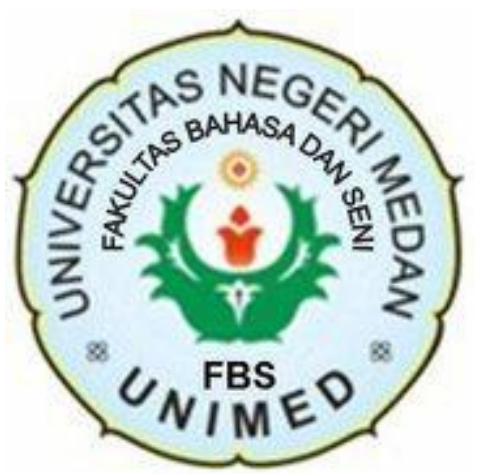

ENGLISH LITERATURE DEPARTMENT

FACULTY OF LANGUAGES AND ARTS

STATE UNIVERSITY OF MEDAN

2017 
ARTIKEL

ASSOCIATIVE MEANING IN HOHO LYRICS OF NIAS TRADITIONAL SONG

Disusun dan Diajukan oleh:

Devy Kristiana Wau

NIM. 2121220003

Telah diverifikasi dan dinyatakan memenuhi syarat untuk diunggah pada jurnal online

Medan, Juli 2017

Menyetujui

Dosen Pembimbing Skripsi I

Mlawullawing' 's' NIP. 198306102008011007

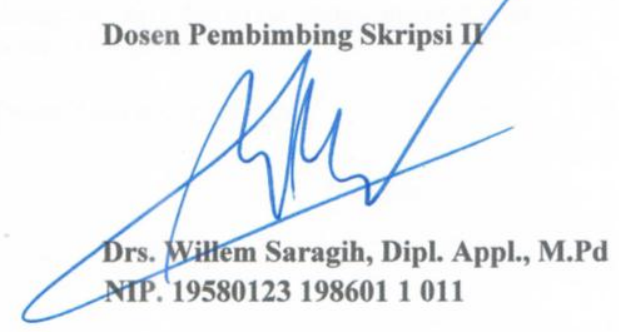

Ka. Program Studi

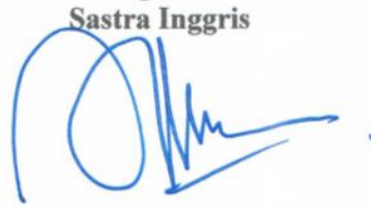

Juli Rachmadani Hasibuan, S.S., M.Hum.

NIP. 198207112008012008 


\title{
ASSOCIATIVE MEANING IN HOHO LYRICS OF NIAS TRADITIONAL
} SONG

\author{
* Devy Kristiana Wau \\ ** Immanuel Prastya Gintings, S.S., M.Hum. \\ ** Drs. Willem Saragih, M.Pd.
}

\begin{abstract}
Wau, Devy Kristiana. 2121220003. Associative Meaning in Hoho Lyrics of Nias Traditional Song. A Thesis. Faculty of Languages and Arts. State University of Medan. 2017.
\end{abstract}

This study deals with the use of Associative meaning in Hoho lyrics of Nias traditional songs which consisted of 4 songs, they are hoho wangowai dome, hoho famadaya hasijimate, hoho moyo, and hoho faluaya. The objectives of this study were to to find out the types of associative meaning and to describe the types of associative meaning of hoho lyrics. This research used descriptive qualitative research.There were five types of associative meaning applied in hoho lyrics namely, connotative meaning, stylistic meaning, affective meaning, reflected meaning and collocative meaning. The data were taken from the words, phrases or sentences from hoho lyrics. The finding implied that the number of associative meaning was described as follows: connotative meaning 50\%, stylistic meaning $16,74 \%$, affective meaning $23,47 \%$, reflected meaning $7,05 \%$, and collocative meaning 2,95\%. Out of 170 hoho expressions there were 85 expressions which belong to connotative meaning. It indicated that the most dominantly type used was connotative meaning with percentage of $50 \%$ due to the song contained with prayer, victory, happiness, honour, wishes or hopes.

Keywords: Hoho, lyrics,traditional song,Associative Meaning

\footnotetext{
* Graduate Status
}

** Lecturer Status 


\section{INTRODUCTION}

\section{Background of the Study}

Language functions as one of the most important parts of human life which deals with society as a tool to communicate and transfer information to other people. Language is inseparable from human beings as it is used in the whole aspects of life as the result. People cannot express their opinion, idea, and mind without language.

Fromkin (2007:8) says human use language as a tool of communication to convey uttered meaning by a person to another one either in written or spoken language. Language is complex symbolic system that people use to communicate and to transmit the culture. As Ferraro (2003:2) states that culture is everything that people have, think, and do as member of society.

Indonesia is a country that has a lot of cultures that need to be developed and protected.It is constituted by numerous tribes such as Bataknese,Nias, Javanese, Karonese,etc. Each tribe has different language to communicate and share ideas of their culture through oral tradition or folklore like in the form of traditional song, poems, music, rhyme, folktale, legend, hoho, etc which are expressed through traditional dance or even in ceremonial events (wedding, funeral, or thanksgiving,etc). Those consist of words, phrases and sentences whose implied meaning which sometimes cannot be understood by the otherpeople. Moreover this study deals with semantics in which words and sentences convey meaning. 
Leech (2003:29) says that meaning is idea or concept that can be transferred from the mind of the speaker in the mind of the hearer by embodying them in the form of one language or another. Meaning must be completed with context in accordance with the time and space in which an expression is applied because similar expression may have different meaning if it is used in different condition or context.

For Nias people (Ono Niha), one way to express their culture is through traditional song which is called as hoho. The terminology of hoho is not familiar to everyone who ever heard hoho. Mendrofa (1981: x) says, hoho is known as literary works. Hoho can be found in Nias traditional ceremonies such as in traditional dance, wedding ceremony, or funeral tradition. Hoho is one of the oral tradition that tells about past events like history (origin of Nias and their ancestor),customs, religions, and philosophies of Nias culture. Hoho functions as a medium of communication, entertainment, ceremoniesor certain ritual. Particularly, it is described as a characeristic or a feature of Nias culture through text or lyric which conveys the meaning about moral messages to the listeners.

Hoho contains an implicit meaning. Its lyric is poem but it is served in song form. The language that is used by the speaker in this oral tradition is arranged well and attractively. Moreover, the use of language in hoho lyrics contains personal feeling expression which include associative or connotative elements. Associative meaning is also like figures of speech. It is the meaning of words that has connection to the relationship of word with the condition beyond the language. Leech (2003:29) states that associative meaning is unstable meaning 
and has variants of individual experience (based on culture, historical period, and the experience of the individual).

For example hoho famadaya hasijimate which can be found in funeral tradition;

Be'e khögu lakhömimö ama,

Give me your both charisma and wisdom, Dad

Fo'ahulua, fo'alöföa.

Blessed and blasted me your livelihood.

The lyrics is connotative meaning.It shows from the word charisma means appeal or characteristic of someone. As we know, it is related to personality of someone like face shape, speaking style, or eye contact or even attitude or behaviour which make people interested and influenced. While, in this lyric the speaker images the words of charisma as wisdom, talent or power. Therefore, the lyrics mean a son who asks for his father's blessing to be able continuing the father's footstep such as his behavior and the goodness that have been done during his lifetime, because Nias people believe the wisdom from the spirits of the deceased person is needed as the prayer for prosperity to continue what has been passed down by father towards the son.

However, people would have different associative meanings from one culture to another because, people living in a different environment, with different cultural backgrounds and customs, way of life, beliefs and traditions, habits,moral,system of values or even world perception (Guimei,2009).

Unfortunately, hoho which is inherited from generation to the generation is only known by limited number of people. In addition, the use of hoho in Nias traditional ceremonies has been reduced and slowly dissappeared over the times. 
So many versions of messages which are conveyed in hoho. In these current days, there is no $E_{r} e^{1}$ in Nias. They have been gone and buried together with their knowledge. Furthermore, a large number of Nias youth have no idea about norms, custom and the real traditional ceremony anymore.

There are some previous studies related to this research. Fanni (2015) studied about types of associative meaning of Maher Zain's song lyric and its relationship with the hadith of the prophet. She used descriptive approach because this research tends to words, phrases or sentences of the associative meanings. The result of her research showed that there were thirthy six of associative meanings in song lyrics of Maher Zain and its relationship with hadith of the prophet. Moreover, the song lyric of Maher Zain has connection with hadiths of the Prophetabout orphans, murder, mother or parents, life in the world, life in hereafter, the big sins, the presence of ease after sorrow, spirit for useful things and the brotherhood in Islam.

Another research by Suryana (2012)studied about the associative and symbolic meaning in Lir-ilir song lyrics by Sunan Kalijaga. Her study showed that the lyrics of the song full about human life, sithe of Islamic as well as delivery by using soft strains to reach the succeed in preaching. She also found the symbolic meaning of the song lyrics have the implicit meaning about Islamic da'wah and its connection with religious messages on implementing the Islamic sharia, compliance in religion. sins and repetences and leadership.

${ }^{1}$ Ere: reliable expert, it usually traditional leaders 
Rahayu (2013) conducted a research about Associative Meaning in Gundul-Gundul Pacul Cul lyrics of Javanese's song. She found that there were the associative meaning, connotative meaning, stylistic meaning, affective, reflected and collocative meaning which contains with the implicit meaning about to persuade, a messages to behve properly, and carry out the mandate properly and responsibly. She found that almost Gundul-Gundul Pacul Cul lyrics contained with connotative meaning which telling about teaching of life as a leader who trustworthy and responsible to all the people.

For those previous studies above, this research will be different especially from the object.The researcher choose this topic because it is interesting to be analyzed. Besides that, the words or the sentences of hoho lyrics is arranged attractively and beautifully. So it contains with implicit value and moral messages of culture.

As a young generation of Niasnese the researcher is attracted to deepen her knowledge about this tradition because it is one of citizen duties to preserve her own culture.Thus, this research is going to analyze and explore the meanings realized in hoho lyric based on Leech theory by using associative meaning, they are: connotative meaning, stylistic meaning, affective meaning, reflected meaning, and collocative meaning. 


\section{REVIEW OF LITERATURE}

\section{Semantics}

Semantics is one of linguistics branches that studies about meaning. It is considered as a major branch of linguistics devoted to the study of meaning in language. Etymologically, the word semantics comes from greek word "semantikos"which means significant; "semaine" means to show, signify or indicate by a sign; from "sema" means sign. Moreover, Mao (2013: 614) states that semantics deals with the study of meaning of linguistic units, words and sentences.

Leech (1969 : 5) states that "The aim of semantics is to explain and describe the meaning in natural language. To make our starting point in ordinary usage more explicit, we may even say that the goal of semantics is explain what underlies the use of the word means and relatedterm (sense, nonsense, signify, ambiguous, antonimy, synonymy, etc) in English and other language".

Semantics is also the core study of the human mind-thought process, cognition, and conceptualization. All these are intricately bound up with the way in which we clasiffy and convey the experience of the world through language. It can be concluded that, semantics is a part of linguistics study that refers to the study of meaning, changes in the meaning and relationship between words with the concepts or the meaning of the word, as weel as objects or things that are reffered by the meaning of beyond language.

Djajasudarma in Fani (2010:9) states that the maint point of study meaning is to understand each other. So that, each person knows what the speaker means and what will be received by the hearer. 


\section{a. Meaning}

The term meaning is simply derived from the word mean. Meaning is regarded as the message that is intended or expressed or signified. In other word, it can be said that meaning is the intended aim.

Palmer (1991:7) states that meaning has a wide scope to be defined, it is not rarely causing a variation in intrepreting a meaning. The definition of it also being diverse because meaning do not seems to be stable but depend upon speakers, hearer and the context. The meaning of a word is defined in part by its relations with other words in the language. Meaning must be something that in the mind rather the word and it must be abstract than pictures and more than just features.

Leech (1981:22) says that the importance of meaning in communication is become the media between the speaker and the hearer to understand each other. We can investigate easily the difference between how to deliver the meaning and how to make the hearer understand the intention.

Leech's types division of meaning can be describe in below:

\section{1).Conceptual Meaning}

Conceptual meaning is called 'denotative' or 'cognitive' meaning. it refers to logical, cognitive or denotative content. It is the basic proportional meaning which correspondens to the primary dictionary definition

Conceptual meaning is the literal meaning of the word indicating the idea or concept to which it refers. Moreover, it deals with the core meaning of expression. For example: 
a) House has a conceptual meaning which means a building made for people live in.

b) Horse means a kind of animal which has four legs, a mane and a tail.

The aim of conceptual meaning is to provide an appropriate semantic representation to a sentence or statement. Sentence is made of abstract symbols. Futhermore, conceptual meaning helps us to distinguish one real meaning from the meaning of other sentences.Thus,conceptual meaning is an essential part of language.Languageessentially depends on conceptual meaning for communication.

\section{2). Thematic Meaning}

Leech (1974:22) says that thematic meaning is the meaning arising out of the way in which the writer or speaker organizes his message.

Example: Tomorrow I plan to have an outing. I plan to have an outing tomorrow.

Certainly these have different communicative values in that they suggest different context: the active sentence answers an implicit question "When will you have an outing?" While the passive sentence answer is an implicit question "What will you do tomorrow?"

Thematic meaning means the meanings of language that is communicated by the way in which a speaker or writer organizes the message, in terms of ordering, focusing, and emphasizing.

\section{3). Associative Meaning}

Leech (1981:12) divides meaning based on communicative value because he saw that the language is as communication tools which means interpreting the environment, classifying or conceptualizing the experience and determining the 
structure of reality which is used to study and observe the present and the future. Associative meaning is different from conceptual meaning (Yule,1985:92). It is the lexical or literal meaning. It can be called by denotative or cognitive meaning that is considered to be the real meaning of the words or sentences.Sarifah (2008:11) emphasizes that associative meaning is the sense associations that have variants meaning based on individual experience or context of the sentences.

In other words, it is the meaning of words that has connection to the relationship of word with the condition beyond the language. For instance, the word "black" is associated with the meaning of darkness and sadness; the word "jasmine" is assosiated with the meaning of holy. Therefore, associative meanings can be affected by the culture and the human experience. As Leech (1981:29) states that associative meaning is unstable meaning and has variants of individual experience. They can be broken up into five subtypes are connotative meaning, stylistic meaning, affective meaning, reflected meaning, and collocative meaning.

\section{a. Types of Associative meaning}

\section{1). Connotative Meaning}

Leech (2003: 23) defines that connotative meaning is the communicative value of an expression according to what is referred to, exceed the above contents are purely conceptual. Italso includes not only physical characteristic, but also social properties and psychologycal. For example:the word "woman" as conceptual meaning has three characteristics "manusia, perempuan, dewasa" (+human,-male, adult). Meanwhile, there isa multitude of additional, non creational properties that we have learnt to expect a referent of woman possess. 
They include physical charachteristics such as "having womb". It also contains of phsycological and social properties such as "gregarious and having maternal instinct".

\section{2). Stylistic Meaning}

Leech (2003: 25) states that stylistic meaning is also called social meaning. It is a part of language which conveys about the social circumstances of its use. Language that we use incommunication is related to the social circumtances of the speaker's culture. It is because the dialects appear from the variety of people's background. The difference of tone, style or choice of wordswill influence their pronunciation. Further, Leech (2003: 25) also states that there is category of the main stylistic variation to distinguish on each dimension which shows something from different style, they are: dialect (the geography language area or social class); time (the language of the eighteenth century); province (language of law, science, etc); status ( polite, colloquial, slang); modality and singularity. Beside that, this type of meaning also emphasizes in greetings, apologies, blessings or condolences. For example: The word Mother have the same conceptual meaning but the convey different social circumstances of their use. For example;

a). Mother (formal), mom (colloquial), mama (child's language).

b). Nias people in northern says "He zomöiö?" while in southern of Nias, the people say "He gaga Möi ?". This sentence has the same meaning “ Where are you going" but have different dialect . 


\section{3). Affective Meaning}

Affective meaning in language is used to express personal feelings or attitudes to the listener. Leech (1981:18) says that it is kind of language which reflects the personal feelings of the speaker including his attitude towards something he is talking about. It expresses the speaker's emotion or feeling about something that is happened according to the situation because Associative meaning relates with the emotive devices.

For example, someone who is addressed: 'You're a vicious tyrant and a villainous reprobate, and I hate you for it!' is left in little doubt as to the feelingsof the speaker towards him. But there are less direct ways of disclosing our attitude than this, such as by scaling our remarks according to politeness. With the object of getting people to be quiet, we might say either:

a). I'm terribly sorry interrupt, but I wonder if you would be so kind as to lower your voices a little.

b). Will you belt up.

Factors such as intonation and tone of voice are important things. The impression of politeness in (1) can be reserved by a tone of biting sarcasm, sentence (2) can be turned into a playful remark between intimates if delivered with the intonation of a mild request.

\section{4). Reflected Meaning}

Leech (2003:29) conveys that what is communicated through association with another sense of the same expression or the meaning which arises in case of multiple conceptual meaning when one sense of word forms part of our response to another sense. It means that one sense of a particular word affects the understanding and usage of all other senses of world. This is usually caused when 
familiarity with one sense of a word affects our interpretation of another sense. We are easy to find reflected meaning in poetry because heightened sensitivity to language in all respects.

\section{5). Collocative Meaning}

Leech (2003:30) states that collocative meaning consists of the associations a word acquires on account of the meanings of words which tend to occur in its environment. For example, the words pretty and handsome. Pretty and handsome share common ground in the meaning "good looking", but may be distinguished by the range of nouns with which they are likely to co-occur or collocate.

Pretty : girl, boy, woman, flower, garden, colour, village, etc Handsome: boy, man, car, vessel, overcoat, airliner, typewriter, etc.

So, the meaning of collocation words have different meaning based on linguistics context in which it is used.

Finally, classification of associative meanings based on Leech's theory which consist of five meanings can be sumarry on the table below:

Table 2.1 Types of Associative meaning (Leech theory 1981:36)

\begin{tabular}{|c|c|l|}
\hline \multirow{4}{*}{$\begin{array}{c}\text { Associative } \\
\text { Meaning }\end{array}$} & $\begin{array}{c}\text { Connotative } \\
\text { Meaning }\end{array}$ & $\begin{array}{l}\text { What is communicative by virtue of what } \\
\text { language use }\end{array}$ \\
\cline { 2 - 3 } & Stylistic Meaning & $\begin{array}{l}\text { What is communicated of the social } \\
\text { circumtances of language use }\end{array}$ \\
\cline { 2 - 3 } & Reflective Meaning & $\begin{array}{l}\text { What is communicated through association } \\
\text { with another sense of the same expression } \\
\text { attitudes by the speaker or writer }\end{array}$ \\
\cline { 2 - 3 } & $\begin{array}{l}\text { Collocative } \\
\text { Meaning }\end{array}$ & $\begin{array}{l}\text { What is communicated through association } \\
\text { with words which tend to occur in the } \\
\text { environment of another word }\end{array}$ \\
\hline
\end{tabular}




\section{RESEARCH METHOD}

This study was conducted by descriptive qualitative method. Daymon and Holloway (2002:14) say, qualitative research is concerned on words rather than numbers. The researcher analyzed the data based on related theory then elaborated it to strengthen the finding. It described the types of associative meaning in hoho lyric of Nias traditional song and explained the interpretation of hoho lyric through associative meaning classifications.

The source of the data was hoho lyrics of Nias traditional song. There were four hoho which have been analyzed based on the types of associative meaning, they were ;hohowangowai dome,hohofamadayahasijimate, hohomoyo ,and hoho faluaya. The words, phrases and sentences in hoho lyrics were the data of this research.

After the data were collected, they were analyzed by using some procedures as follows;

1. Identifying the hoho lyrics.

2. Finding and Classifying hoho lyrics into types of associative meaning, they are: connotative meaning, stylistic meaning, affective meaning, reflected meaning, and collocative meaning.

3. Describing the findings of associative meaning's realized in hoho lyrics.

4. Determining the most dominant type of associative meaning in hoho lyrics. 


\section{RESULT AND DISCUSSION}

\section{Result}

After analyzing the collected data, out of the four hoho songs(hoho wangowai dome, hoho famadaya hasijimate, hoho moyo , and hoho faluaya), there were 170 lyrics that indicate to associative meaning term which classified into types of associative meaning. Those 170 lyrics consisted of 85 lyrics in connotative meaning, 28 in stylistic meaning, 40 in affective meaning, 12 in reflected meaning and 5 in collocative meaning. All the types of associative meaning found in the four hoho songs.

Five types of associative meaning of Leech (1983) theory can be obviously realized in hoho lyrics. Their each frequencies can be seen in the table below:

Table 4.7 The Frequencies of Associative Meaning in Hoho lyrics of Nias

Traditional Song

\begin{tabular}{|c|l|c|c|}
\hline No & \multicolumn{1}{|c|}{$\begin{array}{c}\text { Types of Associative } \\
\text { Meaning }\end{array}$} & Frequency & Percentage (\%) \\
\hline 1 & Connotative Meaning & 85 & 50 \\
\hline 2 & Stylistic Meaning & 28 & 16,74 \\
\hline 3 & Affective Meaning & 40 & 25,53 \\
\hline 4 & Reflected Meaning & 12 & 7,05 \\
\hline 5 & Collocative Meaning & 5 & 2,95 \\
\hline & Total & 170 & 100 \\
\hline
\end{tabular}


Based on the table above shows that the most dominant type of associative meaning which was used in the lyrics of hoho songs is Connotative Meaning with its percentage is $50 \%$ There are 170 data of associative meaning from the four songs. Based on Leech theory (1981) connotative meaning is the meaning of word that has relationship with the individual experience and the real world terms. Moreover, the notion of reference overlaps with the conceptual meaning, while affective meaning is about personal feelings or attitudes of the speaker/reader.Connotative and affective has been the most frequently types in the four song because it contained with thoughts, ideas, and feelings of the poet, thus it sings beautifully and affecting the listener.Beside they are used in the these traditional song lyrics are to portray images and build certain atmospheres. They also play an important role in creating particular senses and delivering the messages.

\section{Disscussion}

Hoho is a Nias traditional song that contains implicit meaning and it is sung in the different context such as, hoho wangamoi dome is a companion song of Maena dance that is sung in wedding ceremony. This hoho is also the entertainment in wedding culture ceremony of Niasnese since ancient times. Therefore, if it is not conducted, the guests who come to the wedding ceremony will get disappointment by saying “lö’ami dödöda bawaelöwa balugu da'ö börö melö maena" (Tafönaö,2012). It is the phrase of disappointment of that matter. The hoho lyrics contain of praise and honor to the each bride and groom. Itis certainly sung cheerfully.However, the message implied is referred to irrationality 
in wedding culture of Nias "Böwö sebua" (jujuran yang mahal) has been such popular vocabulary of the wedding matter in Nias.

Then, hoho famadaya hasijimate is a companion song of deceased father. It is religious and full of prayers. While, hoho moyo is a companion song of moyo dance in owasa ceremony as an entertainment. It contains the expression of woman who against her parents willing to be matched by their choice, attached by sadness, anger, and rejection.

Thelast is hoho faluaya which becomes companion song of faluaya dance (thedanceas if warriorsmovement who are in war zone).Every single thing done by Niasnese managed by hoho, as stated by (Hammerle, 1999:25). Hoho in Faluaya is a part of several hoho existed in Nias. It is the expression of happiness toward victory achieved in war zone. It tells about the powerful and strong men shown in Faluaya dance. It also shows the successful from the war. However, the writer found associative meaning in the lyrics based on Leech theory. The factors influenced the oral tradition are conveyed in the different context, the speaker or the addresser, about what,how the situation, for what purpose, in what way, andwhat language variety used. The first type is connotative meaning such as woman, man, father, mother. These words are called connotative meaning because they are usually defined conceptually which have features in real world. Besides, they have physical characteristic, psychological and social characteristic.

The second type is stylistic or social meaning for example; We greet you in the song of maena, forgive all my sins forgive all my mistakes give your blessing for me, your son to be Happy, then the word such as son, mom, and dad. This 
exampleisconsidered as social meaning because it includes greetings statement, apologies statement, sarcasm, colloquial or language that used in daily activity. Then, affective meaning, for example, but when all of you arrived in our hutdon't be shy to come in; our family that has nothingso our hearts fell the joy and happiness when our suitor went to our daughter; He has a lot oftreasures, He has silver and gold; I don't want to be a princess, I oppose to be a wife, I've ashamed you to all people, For Being anembarrassed daughter.

This is called affective meaning because it shows feeling or expression of the singer or listener which includes complement statement, spirited expression, angry feeling, sad feeling, regret feeling and happy feeling.

Another type is reflected meaning. It is communicated through association with another sense of the same expression,because it creates a new sense based on the context in the sentences, the example from the word and phrase are wind, knitting a loom, and pale. The last type is collocative meaning,for example Heart broken, good months, real life, tears of happiness, and proud son.

Futhermore, connotative meaning $(50 \%)$ has been the most dominant typein the four hoho songs because it contains thoughts, ideas, and feelings from the poet, and it produces a beautiful song which affects the listener. Besides, it is used in the traditional song lyrics to portray images and build certain atmospheres. It also plays an important role in creating particular senses and delivering the messages. 
However, this study is appropriate to attract the addressees or readers in formal or non formal situation. In other words, associative meanings can be found in both oral and written expressions. 


\section{CONCLUSION AND SUGGESTION}

\section{Conclusion}

After analyzing the data regarding the types of associative meaning in hoho lyrics of Nias traditional songs, the researcher concludes the conclusions that presented as follows:

1 The five types of associative meaning that are used in hoho lyrics of Nias traditional songs are;(1) connotative meaning, (2) Stylistic Meaning, (3) Affective Meaning, (4) Reflected Meaning, and (5) Collocative Meaning.

2 The most dominant type of associative meaning used in the hoho songs was connotative with percentage of $50 \%$, because it contained thoughts, ideas, and feelings of the singer or speaker. However, connotative meaning used in the traditional song lyrics are to portray images and build certain atmospheres. It also plays an important role in creating particular senses and delivering the messages.

\section{Suggestion}

There are several suggestions that can be offered based on the analysis of the study, they are:

1 For readers, it is better for them to enrich their knowledge in assosiative meaning and be more careful in catching meaning of each text.

2 For Nias teenagers, it is expected that they will obtain more knowledge about hoho as the traditional songs in Nias and interested in analyzing its application of other ceremonies.

3 For other researchers, hopefully, this research can be useful as guidance, inspiration who are interested in studying meaning especially in analyzing associative meaning in another culture and tradition. 


\section{REFERENCES}

Afif, A. (2010). Leluhur Orang Nias dalam Cerita-cerita Lisan Nias. Kontekstualita, 25(1), 53-77.

Azzah, Nurjanah. ( 2012). Meaning in song lyric of Sintren cirebon: Pragmatic study. Surabaya: University of Sunan Ampel

Chunhua, M. (2013).Associative Meaning in Social and Cultural Context. 2nd International Conference on Science and Social Research, (pp.614-617) China: Hunan Vocational College of Commerce.

Dutamurty, E., \&Nenden.(2013). Associative Meaning on www.khilafah.com. Surabaya: Surabaya State University.

Fanni, C.V.(2015). The Associative Meaning in Maher Zain's Song Lyric. Surabaya: State Islamic University Sunan Ampel

Ferraro. (2003). What is culture?. England: University of Warwick

Fromkin,V.,Rotman, R.(2003). An Introduction of Language seventh edition. Boston: Thousand Place

Gulö, Hubari(2011) . The Form,Function And Meaning in Hoho Lyrics of Nias Faluaya Dance. Medan: University of Sumatera

Hämmerle,Johannes M (1999). He’iwisa ba danö Neho?. Gunungsitoli: Yayasan Pusaka Nias

Leech, Geoffry. (1981). Semantics: The Study of Meaning (2nd ed.). New York: Penguin Books

Leech, Geoffrey. (2003). Semantik. Translated by Paina Partana.. Yogyakarta: Pustaka Pelajar.

Lyons, John. (1997). Semantics Volume I. Cambridge: Cambridge Universty Press.

Mendröfa, Sökhi'aro Welther. (1981). Fondrakö Ono Niha: Agama Purba, Hukum Adat, hikayat dan Mitologi masyarakat Nias. Jakarta: Inkultra Foundation.

Palmer, Frank. (1976). Semantics. Cambridge: Cambridge University Press. 
Rahayu, Sri. (2013). Associative Meaning in lyrics of Gundul-Gundul Pacul Cul Javanese's song. Semarang: University of Semarang.

Setia, Eddy. (2006). Kajian Makna Dalam Linguistik.Englonesian: An Indonesian Scientific Journal on Linguistics and Literature, 6 (1), 2033.

Suryana,Intan. (2012). Makna Simbolik dan Makna Konotatif Dalam Syiir Lir-ilir Oleh Sunan Kalijaga.Malang: Universitas Brawijaya Malang.

Tafönaö, (2012). perkawinan Nias daerah Öri Moro’ö. Bandung: Universitas Katolik Parahyangan Bandung

Wiradyana,Ketut. (2008). Peran Folklore Dalam Melegitimasi Kekuasaan Pada Masyarakat Nias Selatan. Medan:Universitas Negeri Medan.

http://www.wacana.co/2009/10/nias-nilai-nilai-sosial-serta-budayanya/ accessed on September 2016

https://dominiriahulu.wordpress.com/2010/03/15/sistem-kekerabatan-masyarakatnias/ accessed on November 2016

https://sisteminformasipulaunias.wordpress.com/category/tradisi-dan-budaya-nias/ accesed on December 16th ,2016; 11:13 P.M

http://rateyourmusic.com/release/album/various_artists_f2/music_of_indonesia_4 _music_of_nias_and_north_sumatra_hoho_gendang_karo_gondang_toba/ac cessed on January 17th, 2017;15:12 P.M 